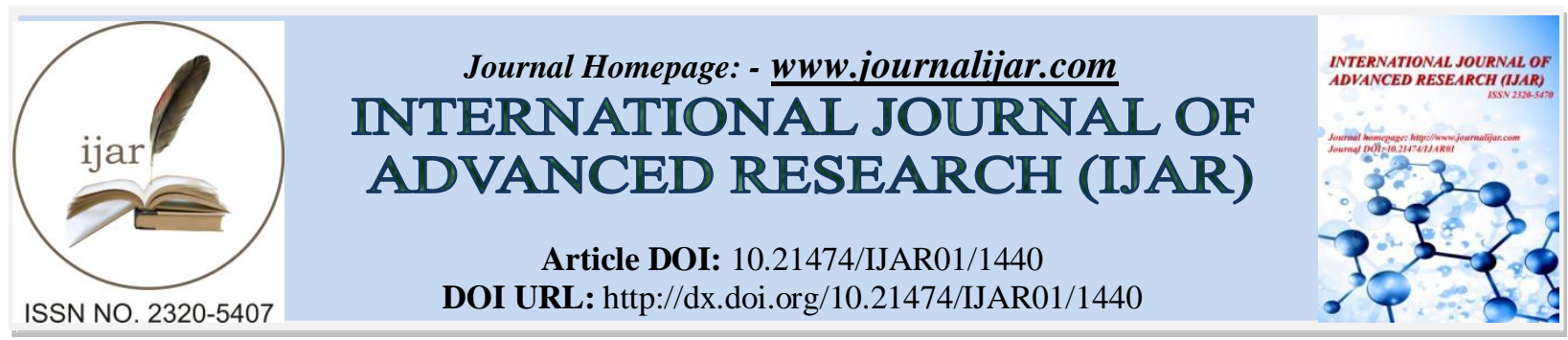

RESEARCH ARTICLE

\title{
SERVICES SECTOR: AN ENGINE OF INCLUSIVE GROWTH IN INDIA.
}

\author{
Dr. Gitte Madhukar Raghunathrao. \\ Associate Professor in economics, Elphinstone College, Mumbai.
}

\section{Manuscript Info}

Manuscript History

Received: 18 June 2016

Final Accepted: 19 July 2016

Published: August 2016

Key words:-

New economic policy, Information technology, Foreign direct investment, Liberalisation, Economic growth,

Knowledge-based economy.

\begin{abstract}
India is one of the fastest growing economies in the world after China. Indian economy was least affected by the global slow down due to strong fundamentals, highly resilient domestic economy, high saving and investment rates and a dynamic and strong service sector. Like other economies in the world, the service sector is the engine of growth of the Indian economy. The services sector in India is one of the major contributor to both national income and employment.

When the New Economic Policy was introduced in 1991, Indian economy underwent a structural transformation from the 'Agricultureled growth' to 'Services-led growth'. India's high growth rate in the post-reform period was mostly achieved and maintained by the spectacular and consistently robust growth of the services sector. Services sector in India is the most dynamic sector, growing at an average annual rate of about 10 per cent, and exhibiting enough resilience to nullify the negative repercussions of the global financial crisis. India is marching towards a service-led export growth rather than manufacturing-led export growth. There are various problems and challenges that are faced by the service sector.
\end{abstract}

\section{Introduction:-}

Service sector is the single largest and fastest growing sector in India contributing more to output and employment. Both India and China are fastest growing economies in the world where services growth rate in China was the highest at 10.5 per cent followed by India with 8.9 per cent. However, share of services in China's GDP was low at 39.2 per cent as compared to India's share of services in its GDP at 60 per cent in 2013-14. The reasons behind the development of the services sector are increasing urbanisation, privatisation, more demand for intermediate and final consumer services, availability of quality services, etc. The growth of services sector was significantly faster and has been continuously above the overall growth of the economy.

There has been a substantial acceleration in services sector growth, especially in the post-liberalisation period. This sector accounts for around 60 per cent share in the GDP, growing by 10 per cent annually, contributing to 28 per cent of total employment, a high share in FDI inflows and over one-third of total exports in recent years.

\section{Objectives of the Study:-}

* To study the role and importance of service sector in country's overall development. 
* To examine the contribution of this sector to GDP, employment, and exports.

* To find out the extent of foreign direct investment (FDI) in this sector.

* To point out various problems faced by the service sector in the economy.

\section{Methodology:-}

The present paper is primarily based on secondary sources of data such as published annual reports of Department of Investment Policy and Promotion, economic survey, government publications, and research articles published in periodicals and journals.

\section{Engine to Economic Growth:-}

The service sector has been recognised the driver of India's economic growth. The growth rate of the economy has increased from 3.6 per cent to 9 per cent during the period of planning due to the accelerated growth rates of industrial and service sectors. The growth rate of agriculture has shown downward trend since 1980, while the industrial and service sectors have continually shown upward trend. The average growth rate of agriculture was below 3 per cent and that of industrial and service sectors, was 5.5 per cent and 6.5 per cent respectively during the period 1950 to 2013. In this way, the growth rate of the economy was pushed up and supported by the service sector by maintaining its own growth rate at a higher level.

\section{Contribution to GDP:-}

These changes in sectoral composition of national income reveal that there has been transformation of the Indian economy from an underdeveloped stage to that of developing stage.

Table 1:- Share of Different Sectors in GDP at Factor Cost ( At 2004-05 Prices)

\begin{tabular}{|l|l|l|l|l|l|}
\hline $\begin{array}{l}\text { Sr. } \\
\text { No. }\end{array}$ & Sector & $\begin{array}{l}1950-51 \\
(\%)\end{array}$ & $\begin{array}{l}1990-91 \\
(\%)\end{array}$ & $\begin{array}{l}2011-12 \\
(\%)\end{array}$ & $\begin{array}{c}2013-14 \\
(\%)\end{array}$ \\
\hline 1. & Agriculture & 56.1 & 33.3 & 16.2 & 13.9 \\
\hline 2. & Industry & 14.4 & 24.1 & 25.5 & 26.2 \\
\hline 3. & Services & 29.5 & 42.6 & 58.3 & 59.9 \\
\hline & Total: & 100.0 & 100.0 & 100.0 & 100.0 \\
\hline
\end{tabular}

Source: Economic Survey 2013-14, Ministry of Finance, GOI, New Delhi, 2014, p.6.

The share of agriculture and allied activities has steadily declined from 56 percent in 1950-51 to 14 percent in 2013-14 due to accelerated growth of industry and service sector. The share of industrial sector in GDP has increased from 14 per cent in 1950-51 to 26 per cent in 2013-14 and is now nearly stable. The share of service sector in GDP has increased very steadily from 29.5 per cent in 1950-51 to about 60 per cent in 2013-14. Even India was able to face the global financial crisis successfully due to the strong hold position of this sector in the economy.

\section{Expanding Share of Different Services:-}

The share of three sub-sectors in the service sector in GDP has increased steadily as follows:

Table 2:- Share of Various Sub-sectors of Services in GDP at Factor Cost ( At 2004-05 Prices)

\begin{tabular}{|l|l|l|l|l|l|l|}
\hline $\begin{array}{l}\text { Sr. } \\
\text { No. }\end{array}$ & Sub-sectors in the Services & $\begin{array}{l}1950-51 \\
(\%)\end{array}$ & $\begin{array}{l}1999-00 \\
(\%)\end{array}$ & $\begin{array}{l}2012-13 \\
(\%)\end{array}$ & $\begin{array}{l}2013-14 \\
(\%)\end{array}$ & $\begin{array}{l}2014-15 \\
(\%)\end{array}$ \\
\hline 1. & $\begin{array}{l}\text { Trade, Hotels, Transport and } \\
\text { Communication }\end{array}$ & 11.3 & 21.2 & 26.9 & 26.4 & 26.7 \\
\hline 2. & $\begin{array}{l}\text { Financing, Insurance, Real estate } \\
\text { and Business Services }\end{array}$ & 7.7 & 14.5 & 19.1 & 20.6 & 20.9 \\
\hline 3. & $\begin{array}{l}\text { Public Administration, Defence and } \\
\text { Other Services }\end{array}$ & 10.5 & 14.4 & 12.8 & 12.9 & 13.4 \\
\hline & Total Share of Service Sector: & 29.5 & 50.1 & 58.8 & 59.9 & 61.0 \\
\hline
\end{tabular}

Source: Economic Survey of India, 2013-14 and 2014-15, Ministry of Finance, GOI, New Delhi, 2014 and 2015, pp. 6 and 108. 
The contribution of economic services to GDP was highest as their share rose from 11 per cent in 1950-51 to 26 per cent in 2013-14. The development of railways, road transport, telecommunication like mobiles was very impressive and have played a major role in the growth of service sector. The share of financial services in GDP has increased from 7.7 per cent to over 20.6 per cent during 1950-51 to 1913-14. The development of financial markets and the boom in the construction industry have mostly contributed to the growth of financial services sector. The share of social, administrative, defence and other services in GDP have also rapidly increased from 10.5 per cent to 13 per cent during the period 1950-51 to 1913-14.

\section{Contribution to Employment:-}

The share of primary sector in employment has declined from 67.5 per cent in 1990-91 to 49.5 per cent in 2013-14, it is still the single largest sector providing employment to half of the working population. The contribution of secondary sector to employment increased from 12 per cent in 1990-91 to 22.5 per cent of the total labour force in 2013-14 due to development of consumer goods industries and construction sector which is highly labour intensive sector.

There has been rapid growth of service sector during the post-reform period which has created substantial employment opportunities in the country. The share of service sector in the employment has increased from 20 per cent in 1990-91 to over 28 per cent in 2013-14. In urban areas, 68.3\% persons were employed in the service sector. Services like trade, travel, tourism and hotels provide the highest employment $(9.4 \%)$ followed by transport, storage and communication services (4.0\%). Employment provided by financial services has increased more than double during the same period. Social, administrative and other services also provide about 10 per cent of the total employment. The service sector has a substantial but untapped employment growth potential particularly in IT and IT-enabled services, telecom services, travel, tourism, healthcare, financial services, retail services, media and entertainment services. There is still much scope for the development of service sector due to low wages and highly educated and skilled personnel.

\section{Contribution to Exports:-}

India was initially exporting mainly agricultural goods which were followed by machinery and manufacturing goods. Due to growth of services sector, its contribution to exports and export earnings has significantly increased. India ranked amongst the first five top export countries in the world in respect of export of services. The services exported are such as computers and information services, commercial services, communication and telecommunication services, business services and other services. The country has a monopoly over the export of IT and ITeS, software's, BPOs and KPOs. The CAGR of merchandise export was about 19 per cent, while it was over 23 per cent of service sector during the period 2000-01 to 2012-13. The share of our country in the world exports of services has increased from merely 0.6 per cent in 1990-91 to 3.3 per cent in 2012-13. The share of services sector to total exports was 32.8 per cent in 2013. In this way, the valuable and much needed foreign exchange is being earned by promoting the exports of various services.

\section{FDI in Service Sector:-}

Inflow of foreign capital particularly foreign direct investment (FDI) plays an important role in the growth of different sectors of the economy. It brings not only foreign exchange and sophisticated technology in the country, but also promotes exports of goods and services and hence, earns foreign exchange. Like other sectors, FDI in the service sector in India has also shown an increasing trend. The share of all services including information and broadcasting, consultancy, hospital, education, retail trading, etc., in total inflows of FDI was 56 per cent in 2012. The financial and non-financial services, construction, computer hardware and software, telecommunications, housing, hotel, travel and tourism services have attracted the maximum FDI at 47 per cent of the cumulative FDI equity inflows in India during the period 2000- 2012. As the government has recognised the role and importance of FDI in the development of services sector, the FDI limit has been increased from 26 per cent to 49 per cent in different services and even 100 per cent in some specific services.

\section{Transition to Knowledge based Economy:-}

The economic liberalisation policy of the government has brought in rapid and drastic changes in the service sector. As a result, there has been an increasing transition of Indian economy from the agrarian economy to a knowledgebased economy. India has a potential to become knowledge-based economy due to fast development of service sector, growth of IT and software sector, largest pool of skilled and highly educated english speaking people and increasing exports of IT based services. The development of the knowledge-based economy depends on creation, 
dissemination and use and application of knowledge in different areas. The Information Technology (IT) and ITenabled Services (ITeS) are recognised as most important pillars of the knowledge economy.

India is being recognised the global knowledge power due to growth of IT and IT enabled services sector. This sector has generated about US \$90 billion and created direct and indirect employment for 11.7 million people in the year 2012 .

\section{Conclusion:-}

It is evident from the forgoing discussion that the service sector is the engine of economic growth especially, "inclusive growth." Policy changes made by the government during the liberalisation period such as changes in FDI limits, tariff rates, subsidy, trade, etc., have given the necessary impetus for the development of the service sector. There are still various challenges before the service sector like retaining existing competitive advantages, enrichment of this sector, tapping and exploring high potential areas of travel and tourism, enhancing exports of education, healthcare and legal services. The government should adopt appropriate strategies for consolidating, strengthening and further growth of the service sector. Service sector specific policies are necessary to achieve the goals of poverty reduction, employment generation, inclusive growth and balanced growth of the economy.

\section{References:-}

1. Government of India (2013): Fact Sheet on Foreign Direct Investment, DIPP, New Delhi.

2. Economic Survey of India (2013-14 and 2014-15): Ministry of Finance, Government of India, New Delhi, 2014. Saravanan, M and Chandrasekaran, B (2011): "Growth Trends in Services Sector," Yojana Monthly, September 2011.

3. Kumar, Akhilesh (2011): " Service Sector: Can It be the Engine of Inclusive Growth," Yojana Monthly, September 2011.

4. Srinivasan, G (2011): "Services Sector and its Contribution to the Indian Economy," Yojana Monthly, September 2011.

5. Roy, Anjan (2011): “Foreign Direct Investment in Services Sector,” Yojana, September, 2011. 